International Journal of English Language and Literature Studies

$\operatorname{ISSN}(e): \quad 2306-0646$

$\operatorname{ISSN}(p): \quad 2306-9910$

DOI: 10.18488/journal.23.2021.103.202.212

Vol. 10, No. 3, 202-212.

(C) 2021 AESS Publications. All Rights Reserved.

URL: wrw.aessweb.com

check for
updates

\title{
WORKPLACE ENGLISH LANGUAGE NEEDS AND THEIR
PEDAGOGICAL IMPLICATIONS IN ESP
}

\author{
D Danebeth Tristeza \\ Glomo-Narzoles $^{1+}$ \\ Donna Tristeza \\ Glomo-Palermo ${ }^{2}$
}

${ }^{1,2}$ University of San Agustin, Iloilo City, Philippines.

'Email.dgnarxoles@gmail.com Tel: +639493651836

'Email:dgpalermo@gmail.com Tel:+639957663310

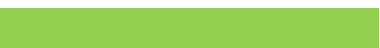

Article History

Received: 27 January 2020 Revised: 29 March 2021

Accepted: 7 May 2021

Published: 2 June 2021

\section{Keywords}

EFL

ESP

Language needs

Language skills

Training needs analysis

Workplace English.

\section{ABSTRACT}

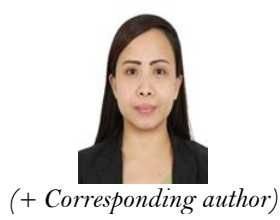

This study aimed to determine the language needs of employees in multinational companies. Results revealed that most of the employees have taken English courses or ESP training besides their formal education. Among the language skills, though speaking is most often used in the workplace but most of them believe that they need to improve all their skills -- speaking, listening, reading and writing to resolve issues. For speaking, they encounter problems like inability to speak with correct grammar and structure; lack of confidence when speaking; and inability to pronounce accurately. The listening problems include unfamiliarity with accents and pronunciation; inability to understand slang, idiomatic expressions or colloquialisms; and inability to comprehend the entire information. The top reading problems are inability to understand due to grammatical weakness; inability to understand words, technical terms, slangs, and idiomatic expressions; and inadequacy of vocabulary in reading. For writing, the problems are inability to use correct grammar and structure; errors in spelling, punctuation, and other technicalities; and difficulty to write messages according to intention. The perceived effects of limited language proficiency of employees in the workplace are: it limits employees' growth potential in the workplace; it causes communication difficulties amongst staff; and it negatively impacts worker safety. Majority of the employees are not provided with any English language course/s or trainings by their companies. The top areas of English language course/training that the employees need are: grammar and structure; basic oral communication skills and writing reports; and filling out workplace forms.

Contribution/ Originality: This study contributes to the existing literature on the training needs of the employees in the English language and how the employers would address them so that the communication barriers would not impede organizational communication.

\section{INTRODUCTION}

In these contemporary times where economy is dependent on business environment, employees are expected to master occupation-specific skills; imbibe information-processing skills, including literacy, numeracy and problem solving; and possess generic skills, such as communication, self-management, and the ability to learn, to adapt to the ever-changing labor market requirements. The principal competencies that are useful and relevant in the workplace are communication skills, critical thinking skills, and human relations skills - where communication skills are the most essential (Julian, Malana, \& Calanoga, 2019). Apparently, since English is the "lingua franca" of business, its role is important for various industries as a means to communicate, negotiate, and carry out the 
employees' duties and responsibilities towards their managers, co-workers, clienteles, and stakeholders. According to Sakitri (2017) English is needed to carry out successful business transactions with customers, to market the products and services, and to develop business. Hence, having a workforce that is fluent in English is a competitive necessity.

Since the diversity of the workplace is constantly shifting, employees are forced to cope with gender, age, and cultural differences. This holds true especially of multinational companies in which varieties of English are used. Along with these differences is the struggle of the employees to communicate effectively with their coworkers from various linguistic backgrounds. Multinational corporations encounter challenges in the field of time differences, communication barrier, perception of others, and cultural or geographical proximity. Language barrier is therefore the main cause of miscommunication in organizations (Erkkila, 2010).

According to a recent survey, more than 70 percent of employees want their companies to improve communication (Golcalves, 2016). This has been confirmed by another survey of 600 employees of multinational companies in which language barriers were listed as a reason why $40 \%$ of international companies were not doing well. Moreover, $64 \%$ of top management agreed that employee-customer communications are the primary language challenge their organizations face. Regrettably, $90 \%$ of international organizations combat language barriers in their day-to-day activities (Rosetta Stone, 2015). A cross-functional and formal language training is deemed to solve this organizational communication issue.

However, only 30\% of companies invest in foreign language skills training. Undeniably, the top management is oblivious of the communication barriers which can impede productivity, teamwork, customer retention, business development, and even lead to security and safety concerns (Association for Talent and Development, 2015). A vast majority of employees, $81 \%$ of them, noted that language training could make them feel that their employers take an interest in their professional development. Accordingly, multinational companies must initiate programs which identify the language training needs of their employees. A number of researches have investigated the English language needs of the employees in the financial, manufacturing, healthcare, hospitality and tourism, and education sectors in other countries. Concomitantly, it is important to identify the English language training needs of employees in multinational companies. Acknowledging these employee language needs, the multinational companies may initiate appropriate language trainings or enhance whatever learning and development programs that they have. Therefore, employability skills of the human resources will be upgraded thereby strengthening the knowledge-based economy of the Kingdom. Hence, this research intended to shed light on this.

This present study is backed up by the Critical Theory of Communication in Organizations by Deetz (1982). The theory states that, "Language is the principal medium through which social reality is produced and reproduced. Managers can further a company's health and democratic values by coordinating stakeholder participation, which involves the employees". Deetz utilizes a "communication model" which considers employees' level of involvement with an organization to be vital. The theory also impresses to the companies and organizations that the human resources' involvement and participation aid in shaping the world of work thus, helping the employees in defining their role in the organization. Moreover, the theory also delineates that, "If more organizations took a critical approach there would be greater likelihood of job satisfaction. There will always be dissenters, but the goal seems to be making the work place more cohesive, and developing mutual understanding about an organization's goals. Rather than having a traditional bureaucracy, the organization should seek to improve its relations with the individuals that actually do the work". Hence, this current research focused on identifying the English training needs of the employees and how the employers would address them so that the communication barriers will not impede the attainment of the organizational communication goals. This is best exemplified by Figure 1. 


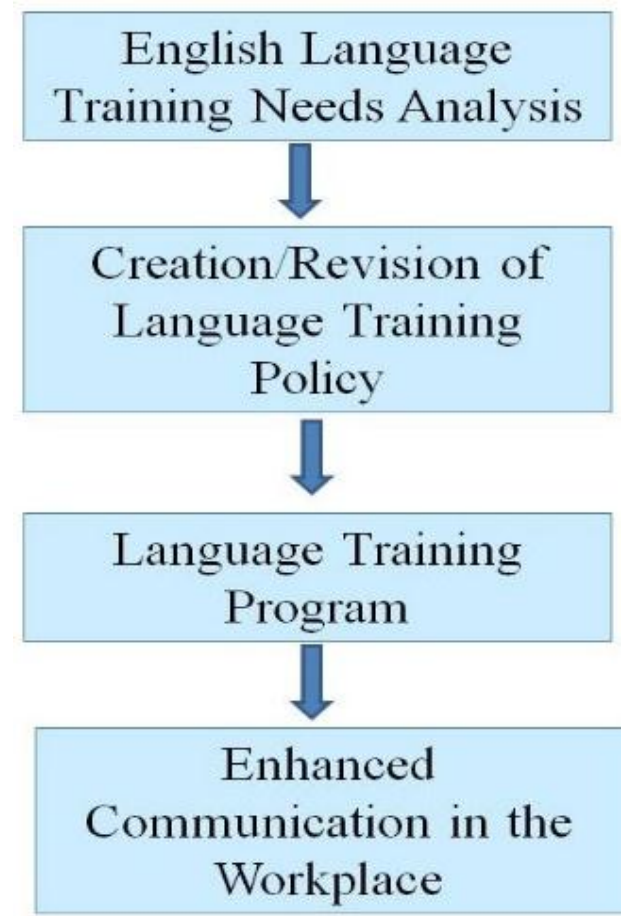

Figure-1. English Language Training Needs Analysis: Basis for the Language Training Program.

To guarantee that English language training programs are relevant to the needs of the employees, information on organizational job, and employee needs should be gathered and analyzed. Needs analysis is said to be the cornerstone of any ESP training course. According to Sredl and Rothwell ( in Luankanokrat (2011)), "Assessing needs is the single most important step in designing human resource development efforts". The needs analysis is the basis of the company's efforts in designing an effective and appropriate language training program.

An important part of the training needs assessment is looking into the lacking skills, contents, and attributes which are imperative for the employees to successfully execute their duties and responsibilities. A number of studies have been conducted on identifying the workplace communication needs of the staff as bases for the human resource programs. One is the study which involved bank employees with different job positions in which the respondents were asked to point out English skills that they need in their job, the problems they encounter using English, and the English training course that they yearn to undergo. Results revealed that the bank employees needed speaking skill the most and majority of them had problems with communication skills. Hence, they noted that the bank must provide English training for them (Mohammadzadeh, 2015).

Likewise, although English is not the medium of communication in their day-to-day activities, financial industry employees prefer to take language training course that would help them in spoken language such as business conversation and presentation skills. Courses have also to include communication strategies and intercultural relations (Wu \& Chin, 2010). Another study analyzed the needs and the dilemma towards English language use of the employees in the tourism industry. The findings show that speaking is most important skill among the language skills and problems in the English use include inappropriate words and expressions, inadequate vocabulary, and lack of grammar knowledge in which training courses are considered vital (Prachanant, 2012). In the study of Chan (2002) employees found out that they needed further training since they were having low proficiency in the communicative activities in the hotel industry.

In addition, a study of employees in retail industry depicted a number of issues on the foundation skills of learning, reading, writing, and oral communication. The lack of customer relations, task organization, sales, and communication skills can adversely affect the retail industry. Thus, trainings to identify, support and mentor entry level employees with foundation skill challenges will be done to address the needs (National Retail Association, 2015). 
In the healthcare sector, a study indicated that the English language is used extensively and plays a crucial role in the career of health practitioners the findings deduced that the English language courses that health practitioners took at the college level were not enough to suffice the communication needs in the medical field. Therefore, applicable language trainings are recommended (Alharby, 2005). Another language needs analysis study was conducted upon HR personnel of multinational companies. The findings showed that communicative events holding and speaking in meetings, writing reports, and editing materials were deemed very important by the respondents. Moreover, the HR staff perceived that they were poor in speaking, reading, and writing. This indicates that the HR personnel need to improve their English language skills and abilities if they wish to perform their tasks more effectively (Kaur \& Clarke, 2009). Another study conducted by Huong (2018) indicated that police officers perform typical activities such as listening to the foreigner complaints/ statements/ explanations, asking personal information from foreign visitors/ immigrants and giving directions to foreign tourists/ visitors, or reminding , among others. The study found out that weaknesses of the police officers included speaking gaps, pronunciation errors, mistakes of preposition as described in the terms of misuse, insertion, and omission, non-mastery of other types of sentences - e.g., simple sentence, complex sentence, and compound sentence, and word choice.

Moreover, the results of the study of Ping and Guo (2019) revealed that students in B-schools have a greater aim for competence in reading and writing e-mails, contracts and annual reports, since all the documents and materials about business are written in English. On the other hand, senior company managers believe that speaking and listening are as important as writing and reading because they are more likely to speak in public and discuss issues with foreigners. The study also found employees' needs for discursive competence in workplaces. Hence, students should be taught ESP-oriented courses which prioritize the common English discursive competences that will be required in the workplace.

The present investigation deems the identification of language training needs to be significant because the differences in communication climates in multinational companies would obviously lead to communication barriers. Dissimilarities in the style of management, attitude and cultural backgrounds of the employees, and communication policies in various cultural contexts of multinational companies add up to the said barriers. When employees and managers do not share the same linguistic and cultural backgrounds, they find it perplexing to express their needs or concerns. On the other hand, when employees and their managers share the same linguistic and cultural backgrounds, they are more at ease in interacting with each other (Gardner \& Liu, 2010). A study on how employees in a multinational company assess their language shows that they themselves judged their competence in language as unsatisfactory and associated workplace communication with "insecurity", "embarrassment", "feeling threatened", "showing weaknesses" and "having no self-confidence". Generally, these emotions are another case of language barrier since they cause workplace dilemma. Hence, it is important that managers address these language barriers induced by emotions. Employees with low language proficiency levels disliked the fact that they had to hold meetings in a foreign language and also disliked native speakers' ability to dominate meetings. As opposed to this, highly proficient employees hated the fact that their less proficient coworkers regularly switched into their mother language during conversations, displacing colleagues who did not speak this language (Tenzer \& Pudelko, 2013).

Learning English should not be considered by employers and employees as a "training opportunity" but a concrete investment in both personal and career growth. Yet, research shows that while $92 \%$ of global employees believe that English is important for their work productivity, only $7 \%$ of non-native speakers of English in multinational companies agree that they can communicate effectively in their workplace (Pearson, 2015). According to Tsurutan (2018) in order to improve the quality of communication, native listeners need to be considerate of the difficulty non-native speakers experience, while non-native speakers need to pay more attention to the appropriateness of their expression. Multilingual teams underscore the fact that managers should consider the impact of language needs, creation or revision of the company's language policy, integration of language training 
needs in the human resource program to have an enhanced workplace communication. All these influence employees' productivity and company's success.

\section{METHODOLOGY}

\subsection{Respondents}

This descriptive research aimed to examine the English language training needs of employees in multinational companies. The main participants were selected through non-probability purposive sampling since the researcher needed to reach a targeted sample composed of employees in multinational companies, particularly those with expatriate employees.

\subsection{Research Questionnaire}

This research utilized a Needs Analysis for English Communication Skills questionnaire adapted from Luankanokrat (2011). Some parts of the said instrument were revised to suit the needs of the present investigation. The questionnaire focused on three areas, namely: I. The Employees' English Language Background; II. The Necessary of English Communication Skills in the Workplace; and III Employees' English Communication Skills Training Needs.

Furthermore, to support the data gathered, a focused group discussion (FGD) was also conducted with the selected employees and employers. Questions regarding the English language training needs of the employees and the learning and development programs of the employers were dealt with in the FGD.

\section{RESULTS AND DISCUSSION}

3.1. The Employees' English Language Background

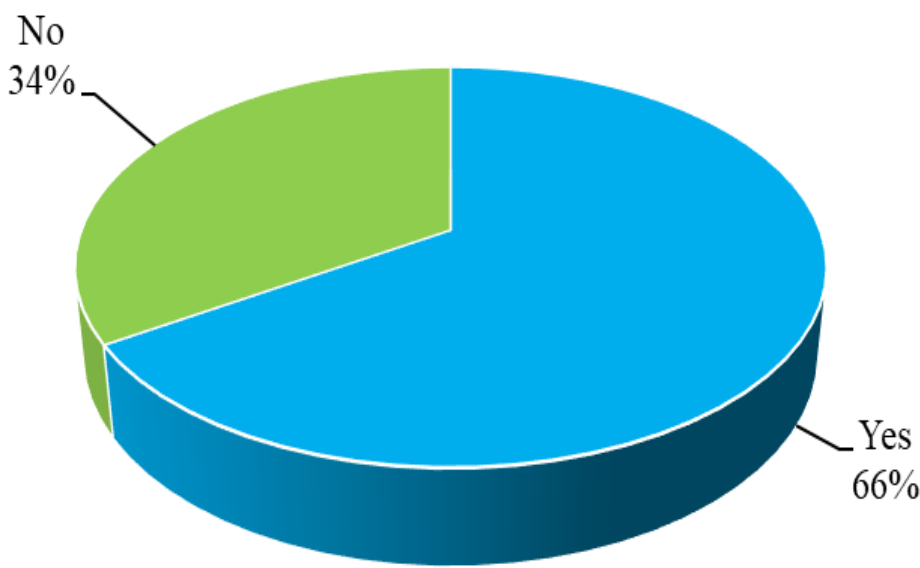

Figure-2. Have the employees taken English course/s or ESP training course/s aside from their formal education?

Figure 2 exhibits that $66 \%$ of the employees in multinational companies had taken English courses or ESP training aside from their formal education while $34 \%$ had not. During the FGD, some of the respondents were asked why they took English courses/trainings aside from their formal education and their responses were as follows: 1." I want to improve my communication skills"; 2. "I took courses which I specifically needed in the workplace"; 3. "I want to be more confident"; and 4. "There are some things which I haven't learned in college so I need to have further training. This has been corroborated by some research findings that the English language courses that they took at the college level were not enough to suffice the communication needs in the medical field. Hence, applicable language trainings have been recommended. However, only $30 \%$ of companies invest in foreign language skills training the reason why employees undergo English courses/trainings at their personal expense. 


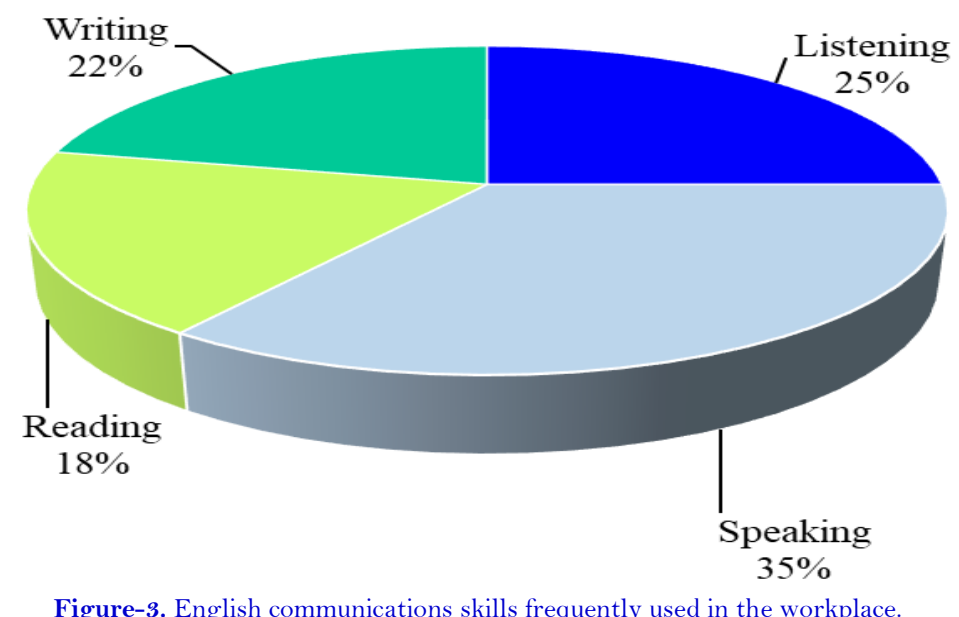

Figure 3 reveals that among the four basic language skills, speaking is most often used in the workplace (35\%), followed by listening (25\%), writing (22\%), and reading (18\%).

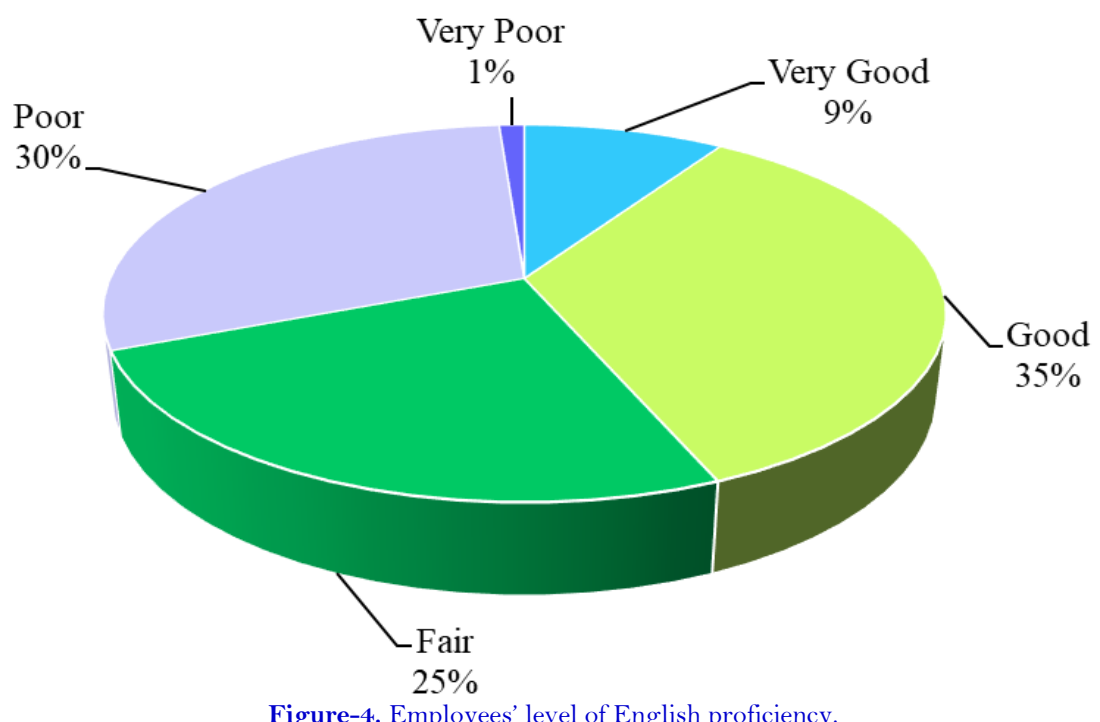

As depicted in Figure 4, most of the employees view their level of English proficiency as good (35\%), followed by poor $(30 \%)$, fair $(25 \%)$, very good $(9 \%)$, and very poor $(1 \%)$. This was corroborated by the responses of some of the respondents during the FGD and short interviews. These are as follows: 1. "I am not confident with my English because I have difficulties in expressing myself in the workplace"; 2. "Sometimes, I use my native language just to communicate effectively in the workplace"; and 3. "I am having difficulties because my English is really bad". These results are backed up by studies on how employees in a multinational company judged their competence in the English language as unsatisfactory and associated workplace communication with "insecurity", "embarrassment", "feeling threatened", "showing weaknesses" and "having no self-confidence". 


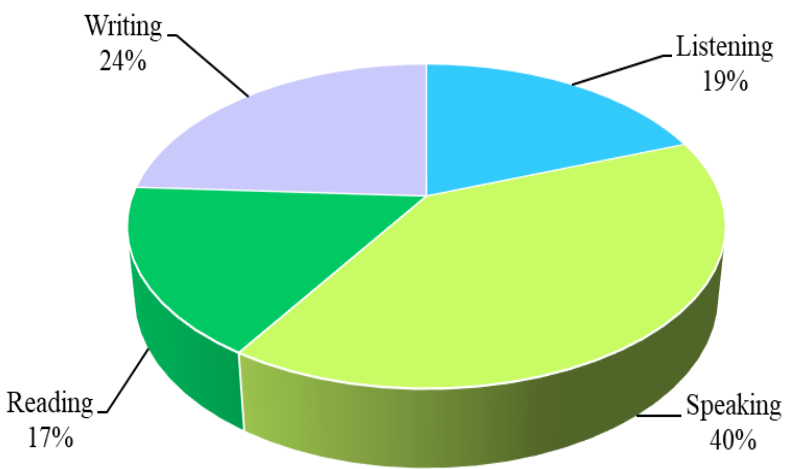

Figure-5. Significant language skills which employees need to improve in their career and work.

Figure 5 reveals that majority of the employees (40\%) believe that they need to improve their English speaking skill. Results are supported by several studies which reveal that bank employees need speaking skill the most and majority of them have problems with all the communication skills; financial industry employees who prefer to take language training course that would help them in spoken language such as business conversation and presentation skills; and the tourism industry employees who believe that speaking is most important skill among the language skills.

\subsection{English Language Problems}

Table-1. Listening Problems

\begin{tabular}{l|c}
\hline Listening & Rank \\
\hline Unfamiliar with other's accents and pronunciation & 1 \\
\hline Unable to understand slang, idiomatic expressions or colloquialisms & 2 \\
\hline Unable to remember the entire information & 3 \\
\hline Incapable of translating words or sentences & 4 \\
\hline Unable to understand technical terms & 5 \\
\hline Unable to catch words or conversations & 6 \\
\hline Others & 7 \\
\hline
\end{tabular}

Based on Table 1, the top three listening problems as perceived by the employees are: (1) Unfamiliarity with accents and pronunciation; (2) Unable to understand slang, idiomatic expressions or colloquialisms; and (3) unable to remember the entire information. These are supported by some research findings which show that communication problems include inappropriate words and expressions linguistic while cultural backgrounds may also affect their interaction because of accents and pronunciation issues.

Table-2. Speaking Problems

\begin{tabular}{l|c}
\hline Speaking & Rank \\
\hline Unable to speak with correct grammar and structure & 1 \\
\hline Not confident when speaking & 2 \\
\hline Unable to pronounce accurately & 3 \\
\hline Unable to choose the right words/Poor in vocabulary & 4 \\
\hline Unable to present or discuss information in correct sequence & 5 \\
\hline Others, specify: & 6 \\
\hline
\end{tabular}

Table 2 shows that the top three speaking problems are: (1) Unable to speak with correct grammar and structure; (2) Not confident when speaking; and (3) Unable to pronounce accurately. These are corroborated by some results which reveal that speaking problems include lack of grammar knowledge and use of inappropriate words. 
Table-3. Reading Problems.

\begin{tabular}{l|c}
\hline Reading & Rank \\
\hline Unable to understand due to grammatical weakness & 1 \\
\hline Unable to understand words, technical terms, slang, idiomatic & 2 \\
\hline Having inadequate vocabulary in reading & 3 \\
\hline Difficulty in understanding unfamiliar passages & 4 \\
\hline Unable to understand complicated texts & 5 \\
\hline Others, specify: & 6 \\
\hline
\end{tabular}

As shown on Table 3, the top reading problems are: (1) Unable to understand due to grammatical weakness; (2) Unable to understand words, technical terms, slang, and idiomatic expressions; and (3) Having inadequate vocabulary in reading. This is supported by research results which depict that reading is one of the problems of employees because of their poor grammar.

Table-4. Writing Problems.

\begin{tabular}{l|c}
\hline Writing & Rank \\
\hline Unable to use correct grammar and structure & 1 \\
\hline Having errors in spelling, punctuation, and other technicalities & 2 \\
\hline Unable to write messages according to intention & 3 \\
\hline Unable to use correct writing format & 4 \\
\hline Difficulty in composing sentences according to purpose & 5 \\
\hline Others, specifv: & 6 \\
\hline
\end{tabular}

Table 4 reveals the top writing problems which are: (1) Unable to use correct grammar and structure; (2) Having errors in spelling, punctuation, and other technicalities; and (3) Unable to write messages according to intention. These are backed up by results which showed that language problems include lack of grammar knowledge and use of inappropriate words.

Table-5. How does the limited language proficiency of the employees affect multinational companies.?

\begin{tabular}{l|c}
\hline Effect & Rank \\
\hline It limits employees' growth potential in the workplace & 1 \\
\hline It causes communication difficulties amongst staff & 2 \\
\hline It negatively impacts worker safety & 3 \\
\hline It increases employee turn-over rates & 4 \\
\hline It limits my company's growth potential and/or competitiveness & 5 \\
\hline It negatively impacts production rates & 6 \\
\hline It negatively impacts customer service & 7 \\
\hline It has no impact in the company & 8 \\
\hline
\end{tabular}

Table 5 depicts the perceived effects of limited language proficiency of employees in the workplace. The top problems are: (1) It limits employees' growth potential in the workplace; (2) It causes communication difficulties amongst staff; and (3) It negatively impacts worker safety. The top management of companies are aware of the communication barriers which can impede productivity, teamwork, customer retention, business development, and even lead to security and safety concerns. 


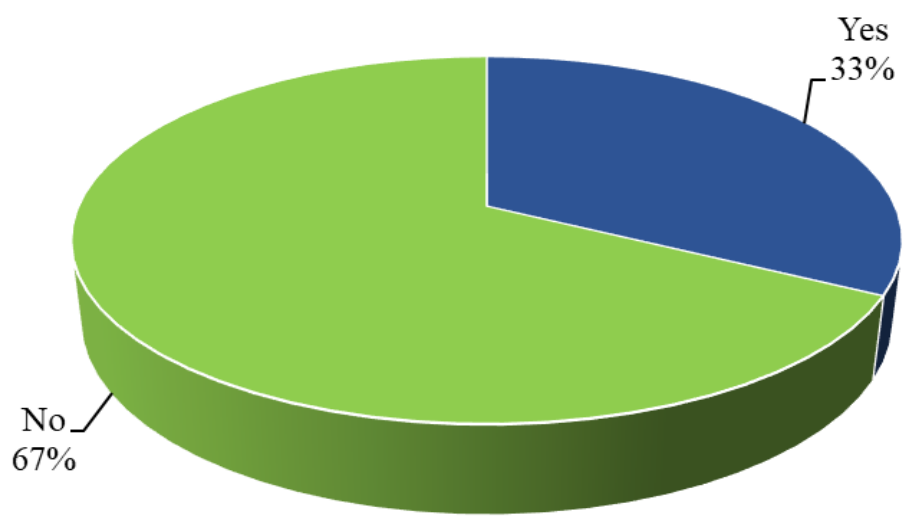

Figure-6. Did the multinational companies provide any English language course/s or training/s to the employees?

Figure 6 reveals that $67 \%$ of the employees were not provided with any English language course/s or trainings by their companies while only $33 \%$ were given such course/training.

Table-6. The areas of English language courses/trainings that employees need

\begin{tabular}{lc}
\hline Area of English language course/training & Rank \\
\hline Grammar and Structure & 1 \\
\hline Basic Oral communication skills (Pronunciation, Intonation, Accent Reduction) & 2.5 \\
\hline Writing reports & 2.5 \\
\hline Filling out workplace forms & 4 \\
\hline Dealing with customers or clients & 5 \\
\hline Understanding work and safety procedures & 6 \\
\hline Learning the technical language/jargon & 7 \\
\hline Conducting surveys & 8 \\
\hline Presentation Skills & 9.5 \\
\hline Intercultural communication & 9.5 \\
\hline
\end{tabular}

Table 6 shows the areas of English language course/training that the employees need. The top three areas are: (1) grammar and structure; (2) basic oral communication skills and writing reports; and (3) filling out workplace forms.

\section{CONCLUSION}

Most of the employees of the multinational companies have taken English courses or English training aside from their formal education at their own expense and majority of those who took English courses or English training were enrolled at the British Council. Among the four basic language skills, speaking is most often used in the workplace, followed by listening, writing,and reading. Moreover, most of the employees view their level of English proficiency as good but majority believe that they need to improve their English speaking skills. The top three listening problems as perceived by the employees are unfamiliarity with accents and pronunciation; inability to understand slang, idiomatic expressions or colloquialisms; and inability to remember the entire information. For speaking, the top problems are inability to speak with correct grammar and structure; lack of confidence when speaking; and inability to pronounce accurately. On the other hand, the top reading problems are inability to understand due to grammatical weakness; inability to understand words, technical terms, slang, and idiomatic expressions; and inadequacy of vocabulary in reading. Lastly, for writing, the problems are inability to use correct grammar and structure; errors in spelling, punctuation, and other technicalities; and difficulty to write messages according to intention.

In addition, the perceived effects of limited language proficiency of employees in the workplace are: it limits employees' growth potential in the workplace; it causes communication difficulties amongst staff; and it negatively 
impacts worker safety. Majority of them, however, are not provided with any English language course/s or trainings by their companies. Hence, the top areas of English language course/training that the employees need are grammar and structure; basic oral communication skills and writing reports; and filling out workplace forms.

\section{RECOMMENDATIONS}

Results of this research imply that English language is very significant in the workplace, most especially in multinational companies. Findings of the present investigation may encourage the employees to reflect on their English language needs and do something to address these needs, with or without their respective company's interventions. The employers of the multinational companies may gain a lot of insights from this research especially in identifying the English language training needs of their employees. They can introduce or revisit their language program, if they have already completed one, to ensure that employees receive the appropriate learning and development initiatives in order for them to perform their daily tasks effectively and efficiently. This can be a form of profitable and sustainable investment in human resources and can be regarded as an important incentive by the employees. As a result, the companies will eventually have an outstanding performance in multilingual business communication.

Results of this present investigation may also give language teachers pertinent information on the language skills gaps that need to be addressed within the four walls of the classroom. Knowledge of the workplace language needs could result to a change of teaching methodologies and materials that target English for Special Purposes (ESP) especially in the areas of finance, engineering, manufacturing, healthcare, and hospitality and tourism among others. The need for language skills is an aspect that has not been much given attention in the context of educationindustry collaborations. Results of this research may lead to possible partnerships of higher education institutions with industries from various sectors to provide opportunities for language teachers to be cognizant of the actual business communication processes. Companies may also have a memorandum of understanding with the education institutions that would encompass employee training in English language competencies and workplace communication. Further research may be conducted on the English language training needs of employees in specific types of industry/sector.

Funding: This study received no specific financial support.

Competing Interests: The authors declare that they have no competing interests.

Acknowledgement: Both authors contributed equally to the conception and design of the study.

\section{REFERENCES}

Alharby, M. (2005). ESP target situation needs analysis: The English language communicative needs as perceived by the health professionals in the Riyadh area. Unpublished PhD Dissertation, Athens: The University of Georgia.

Association for Talent and Development. (2015). Language barriers in the workplace. Retrieved from: https://www.td.org/magazines/td-magazine/language-barriers-in-the-workplace.

Chan, M. Y. (2002). English language communication training needs of front office assistants of hotels in Kuala Lumpur. In Jayakaran Mukundan, Arshad Abd Samad \& Teh Chee Seng (Eds.). Readings in English Language Teaching (ELT) (pp. 35 - 44): Selected Papers from the Millennium MICELT.

Deetz, S. (1982). Critical interpretive research in organizational communication. Western Journal of Speech Communication, 46(Spring 1982), 131-149.

Erkkila, L. (2010). Internal communication issues in a multinational company: Logonet group (pp. 1-39): International Business.

Gardner, K., \& Liu, R. (2010). Claiming their voice: Sociolinguistic factors affecting immigrant workers' Ability to speak up. CATESOL Journal, 21(1), 45-65. 
Golcalves, P. (2016). What employees want: Better communication in the workplace. The Staffing Stream. Retrieved from: http://www.thestaffingstream.com/2017/01/10/what-employees-want-better-communication-inthe-workplace/.

Huong, T. (2018). English language needs in listening and speaking skill of police officers in Vietnam: Basis for ESP Syllabus design. Asian EFL Journal, 14(7.2), 251 - 279.

Julian, C., Malana, M., \& Calanoga, M. C. (2019). How's my English? Communications skills: A relevant indicator of work success. Asian EFL Journal, 24(4.2), 350-376.

Kaur, S., \& Clarke, C. M. (2009). Analysing the English language needs of human resource staff in multinational companies. English for Specific Purposes, 8(3).

Luankanokrat, S. (2011). Needs analysis for english communication skills of employees at HSBS in Thailand: Master of Arts. Thamassat University.

Mohammadzadeh, S. (2015). An investigation into the english language needs of bank employees of Saderat Bank in Mashhad. Theory and Practice in Language Studies, 5(8), 1695-1702.

National Retail Association. (2015). Workplace english, language \& literacy: Research and analysis of issues within the Australian retail industry. Retrieved from: https://www.skillshighway.govt.nz/sites/default/files/documents/WELLResources-ResearchReport.pdf.

Pearson. (2015). Businesses need to invest in employees' English skills to avoid productivity loss. Retrieved from: https://www.pearson.com/news-and-research/announcements/2015/12/businesses-need-to-invest-in-employeesenglish-skills-to-avoid-p.html.

Ping, H., \& Guo, F. (2019). What skills do college students require in the workplace? A research study based on discursive competence. The Asian ESP Journal, 15(1.1), 119 - 140.

Prachanant, N. (2012). Needs analysis on english language use in tourism industry. Paper presented at the The 8th International Language for Specific Purposes (LSP) Seminar - Aligning Theoretical Knowledge with Professional Practice.

Rosetta Stone. (2015). Language means business. Retrieved from: https://resources.rosettastone.com/assets/lp/9999999999/resources/language-means-business.pdf.

Sakitri, W. (2017). Strategies used by indonesia businessmen for communication via email in global trade Era. Asian EFL Journal, 102, 29-57.

Tenzer, H., \& Pudelko, M. (2013). Leading across language barriers: Strategies to mitigate negative language-induced emotions in multinational corporations. Academy of Management Proceedings.

Tsurutan, C. (2018). Tone of voice or what was said? The impression non-native speakers of English make on Australian English native listeners. Journal of English as an International Language, 13(1), 80-90.

Wu, R., \& Chin, J. S. (2010). An Investigation into the English language needs of banking and finance professionals in Taiwan. Semantic Scholar. Retrieved from: https://www.semanticscholar.org/paper/An-Investigation-into-the-EnglishLanguage-Needs-of-Wu-Chin/413efdfoacfo8853b8b21d229ceea91d7a53c003. 